\title{
Development of Multifunctional Software for Business Operations in SMEs
}

IVANA M. BERIĆ, Project management college, Belgrade ACA D. JOVANOVIĆ, Project management college, Belgrade

MILAN M. POPOVIĆ, Montex-Elektronika, Podgorica, Montenegro ALEKSANDAR V. RADULOVIĆ, Montex-Elektronika, Podgorica, Montenegro
Review paper

UDC: 005.8:004.4

DOI: 10.5937/tehnika1605756B

This paper presents the web-oriented software solution focused on supporting the efficient management of operations and projects in SMEs. The development of this software is treated as a separate project and has used agile software development methodologies and specific principles and project management solutions to deliver product in the desired time and in accordance with the requirements of the client.

Key words: managing by projects, business management software, SMEs, project portfolio

\section{INTRODUCTION}

Information systems represent a set of hardware and software solutions composed to assist in the efficient performance of the various business operations. Individual software solutions can be related to one or more business operations and to one or more projects that support the operations of a company.

The main characteristics of modern business are increasing global competition, speed of industrial changes and need to survive in changing environment. Consequently, new IT and management tools, methods and techniques are introduced to mitigate risks and challenges of new business paradigms.

Managing business by projects is becoming a well established and very effective practice [1]. It is a strategy to divide complex business operations in smaller parts - projects, which are easier to manage, not only for their reduced size, but for the sake of large knowledge and experience base acquired in project management theory and practice.

In addition to the traditional project-oriented businesses, such as construction, engineering, and IT, classic "non-project" businesses like manufacturing, banking, tourism, and even administration, turn to projects. It is becoming a common understanding that "everything may be a project".

Author's address: Ivana Berić, Project management college, Belgrade, Bože Jankovića 14

Paper received: 02.09.2016.

Paper accepted: 05.09.2016.
Managing by projects is not considered only as a tool to solve complex problems, but as a new strategic option for the organizational design of companies. Companies using "new" project-oriented organization paradigm while performing small and large projects, internal and external projects, and unique and repetitive projects to cope with new challenges from a dynamic business environment.

Figure 1. shows a possible partition of business operation into the projects. Each project is managed using standard project management procedure, but projects may also, be grouped in project portfolios, and managed as programs. In Figure 1. all of the projects are grouped in one portfolio, but it is easy to imagine the other ways of project grouping.

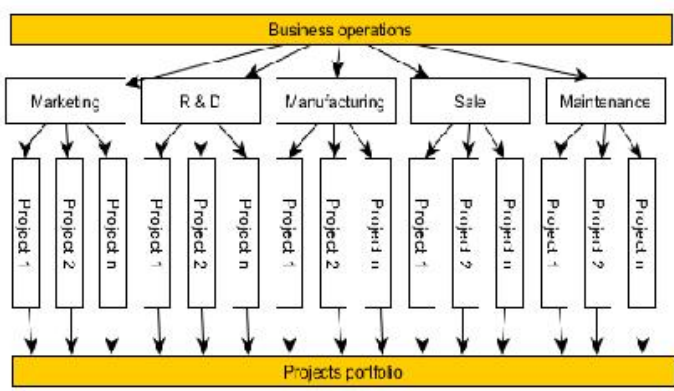

Figure 1 - Partitioning of business operation into projects

As a case study of such an approach we will present a web-oriented software - TimPlaner, used as a tool for managing by projects in Montex Elektronika, a SME company based in Podgorica, Montenegro. The case study shows that managing by projects with agile methodologies may lead to higher team productivity, 
improved team cohesion and collaboration, and better overall company resource utilization [2].

\section{INFORMATION SUPPORT TO THE MANAGEMENT OF BUSINESS PROJECTS IN SMES}

There are many definitions of SME. The European definition of SME is: "The category of micro, small and medium-sized enterprises is made up of enterprises which employ fewer than 250 persons and which have an annual turnover not exceeding 50 million euro, and/or an annual balance sheet total not exceeding 43 million euro." (Extract of Article 2 of the Annex of Recommendation 2003/361/EC). This is a fairly broad definition, and need more specific characterization.

For our purpose, SMEs may be additionally characterized by three keywords - small, single and local:

- Small - SMEs are small in terms of number of employees - 10 persons for 'small' to 250 persons for 'medium'

- Single - Most SMEs have a single owner who could also be the sole employee. The 'single' also refers to single products produced or service provided.

- Local - SMEs are essentially local in nature - their market is usually localized to the area where they are located (same city, district or state).

Managing business by projects has become common practice in some specific areas such as software development and IT implementation, where methodologies like Agile have become a standard. [3] In other area of small and medium business "managing by project" was introduced only recently.

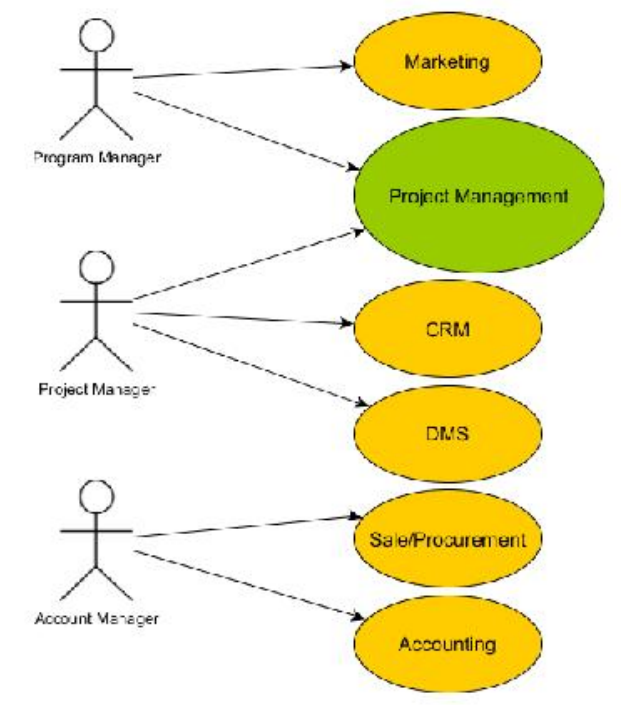

Figure 2 - Typical business organization in a SME

Figure 2. illustrates a typical business organization in SME. Program manager (usually the owner of SME), manages portfolio of all projects in the SME.
Project managers are in charge of separate business activities treated as projects. Business activities may be "standard" projects, but also they may be any kind of business operation.

Almost all activities of SME, regardless of the type of business they are in, may be treated as projects, and projects may be treated as profit centers. Similarly, each company contract may be treated as project. SMEs projects have shorter life cycle (usually less than a year), and smaller project teams (usually less than 10 people), which makes them more appropriate for micromanagement. For such projects, special software is needed, different from standard tools such as MS Project and Primavera.

To create an appropriate software support for project management in SMEs, it is important to analyze the type of projects SMEs are encountering in everyday practice. The classification of such projects and definition of project types with similar characteristics, may help us to precisely identify project specifics, and consequently define concepts and methodologies for managing various types of projects to achieve best practical results.

Taking into account the duration, complexity, required resources and financial means, it is possible, from project management's point of view, to devise four global groups of projects. They are investment projects (building plants, roads, enegry objects etc.), IT projects (software development, information system infastructue, etc.), business projects (marketing, organizational stucture building, etc.), and social projects (organization of music, sport and other social events, etc.) [4]

Software desribed in this paper is designed for the support of typical IT projects, developed with the aim to help SMEs to improve efficience of their everyday operations and project activities.

\section{CASE STUDY: MONTEX-ELEKTRONIKA - MANAGING BY PROJECTS}

Montex-Elektronika (ME) is an IT company located in Podgorica, Montenegro. ME employs 15 people, and is operating for more than 20 years in Montenegro and regional market.

The main business of ME is IT systems integration and implementation. ME business also includes software development, IT system administration and ICT equipment sale and repair. Although on the border between small and medium size, ME is trying to keep going all their traditional services, and to develop new services to satisfy market needs. They are a small team with diversified activities.

For a long time ME management understand that to be successful in small market, one must use the best 
managerial strategies and manage the resources (especially human resources) in the most effective way. Managing by project was ME most recent approach, after using several other strategies and software tools with no full satisfaction.

In 2012 ME decided to develop "in-house" solution, based on their vast experience in problem domain and software development. This is how TimPlaner was born. TimPlaner [5] is an integrated, web- oriented multifunctional business management software covering all standard area of business operations: marketing, sale and procurement, finance, project management, document management, customer relation management, etc. We are not going to present all the features of TimPlaner in here. We will only show how TimPlaner is used for "managing by project" strategy. Figure 3. illustrates how projects are organized and managed in TimPlaner.

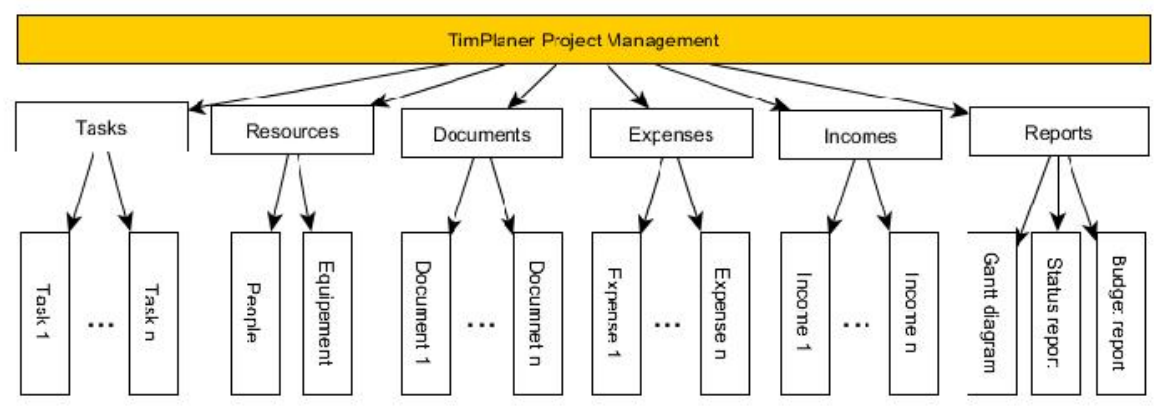

Figure 3 - TimPlaner project management

\section{TimPlaner project organization}

In TimPlaner, program manager and project manager (may be the same person) are assigned for each project. They are "main driving force" cooperating with project stakeholders and company management, and managing project team toward the completion of the project.

Project manager is also, in close communication with account manager for the purpose of managing and controlling project's financial resources. Program manager may be acting as a project sponsor, being a person of higher professional authority and with more influence in company management.

Team members are responsible for assigned tasks. During task execution they plan daily activities (calendar), make notes and reports, and create various project documents (technical drawings, computer code, GUI design, etc.).

Figure 4. shows a part of TimPlaner project management functionality.

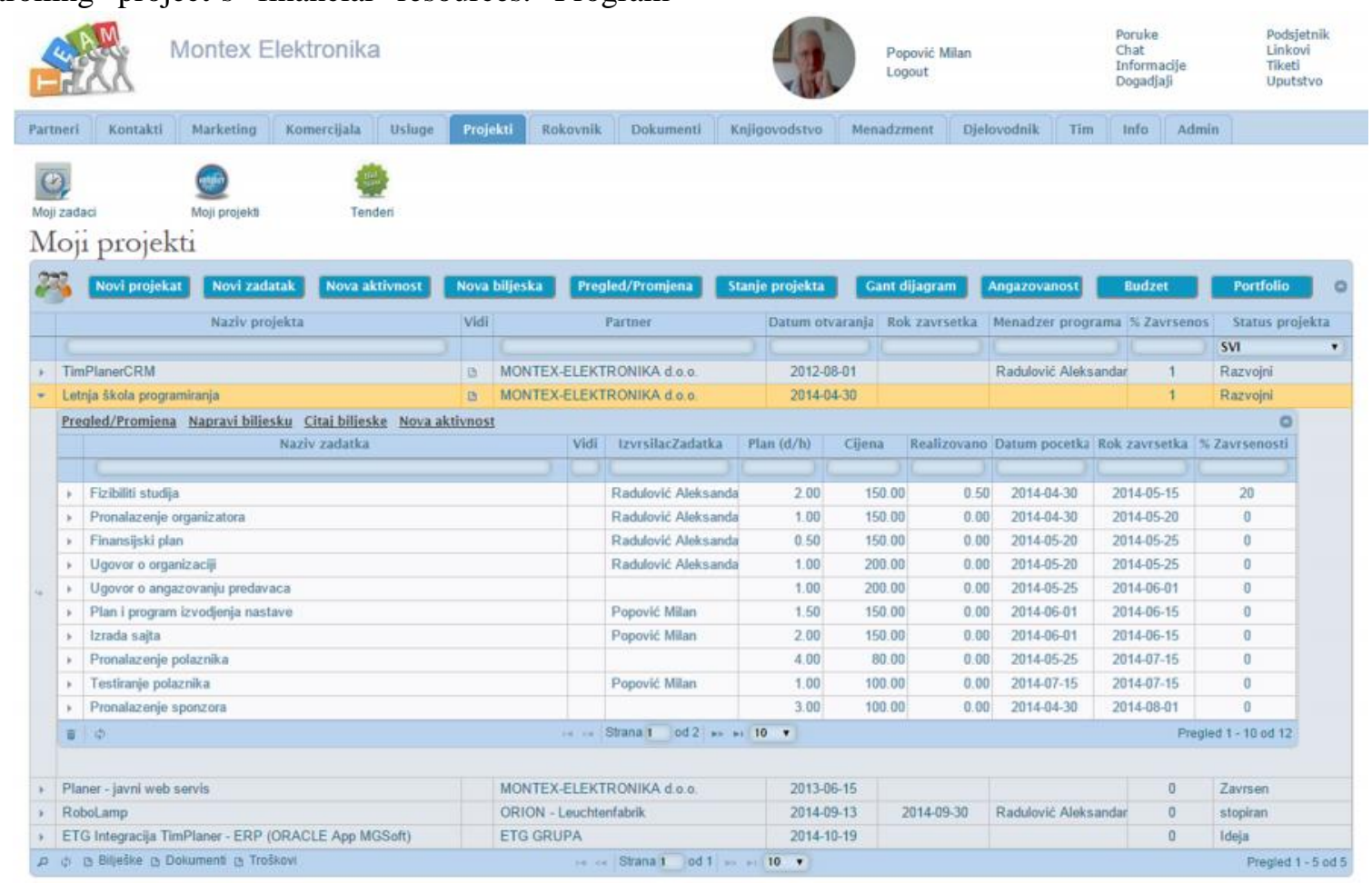

Figure 4 - TimPlaner Project 
TimPlaner is designed with the aim to support business operation partitioning in projects as described before. Now, we will briefly describe TimPlaner capabilities in dealing with standard project management processes: initiation, planning, executing, monitoring and control, and closing [6].

\section{TimPlaner project initiating}

In TimPlaner, a projects are created at the time of the birth of new ideas and after their approval by the top management. Various initial documents are created elaborating and supporting business idea - white papers, feasibility studies, market research, etc. TimPlaner supports three kinds of document: internally created using a built-in editor, uploaded in any of the known format (doc, pdf, xls, etc.), and linked documents, also of any kind. At the end of initiating phase, a project description document summarizing all initiating efforts and findings, is created. This document makes the basis for deciding of further project destiny. If approved by top management, next project phase is followed. If not project is dead.

In initiating phase, only project manager is defined, but he may engage people for different preliminary tasks needed in this phase.

\section{TimPlaner project planning}

TimPlaner is designed with Agile methodology in mind. Thus, planning is a continual process. Initial plan covers only main project activities and milestones, with rough estimations on time and other resources needed during project life time. Detailed planning is done in the course of project. For each task, in detail plan, a responsible person is defined, estimation of her/his time engagement (in hours or days) is stated, start and finish dates of the task are defined, and planned expenses (travel, equipment, material, etc) for executing the task are entered.

\section{TimPlaner project monitoring and control}

In TimPlaner, projects may have both project manager and program manager (if project is a part of a program). Project manager monitors the program by following reports and notes that project team members post in project. Project members have three options for posting reports: short task reports as part of task assignment, notes created whenever is needed, and project documents (state reports, issues, technical reports etc.).

As it can be seen in Figure 4, Project management part of TimPlaner has a comprehensive functionality for monitoring and control of a project, including Gantt diagrams, project status diagrams, project budgeting, as well as project portfolio reporting. Projects are interconnected with other parts of software: documents, invoices, orders, payments, calendar activities, etc.

While project manager and project team members are in close interaction, program manager may only monitor their activities, and make notes to project manager and/or project team member .

In TimPlaner, project details are visible only to project manager, program manager, and project team (for their own tasks). Top management of the company has a special access to monitor all the projects and programs, with special aggregated reporting.

\section{TimPlaner project closing}

When project is finished, final reports are generated as separate internal documents. The whole project is then archived for postproject analysis and for company knowledge and experience mining.

For illustration of TimPlaner module's interconnectivity we show only one more screenshot of TimPlaner in Figure 5, which illustrates the connection between Invoices and Projects.

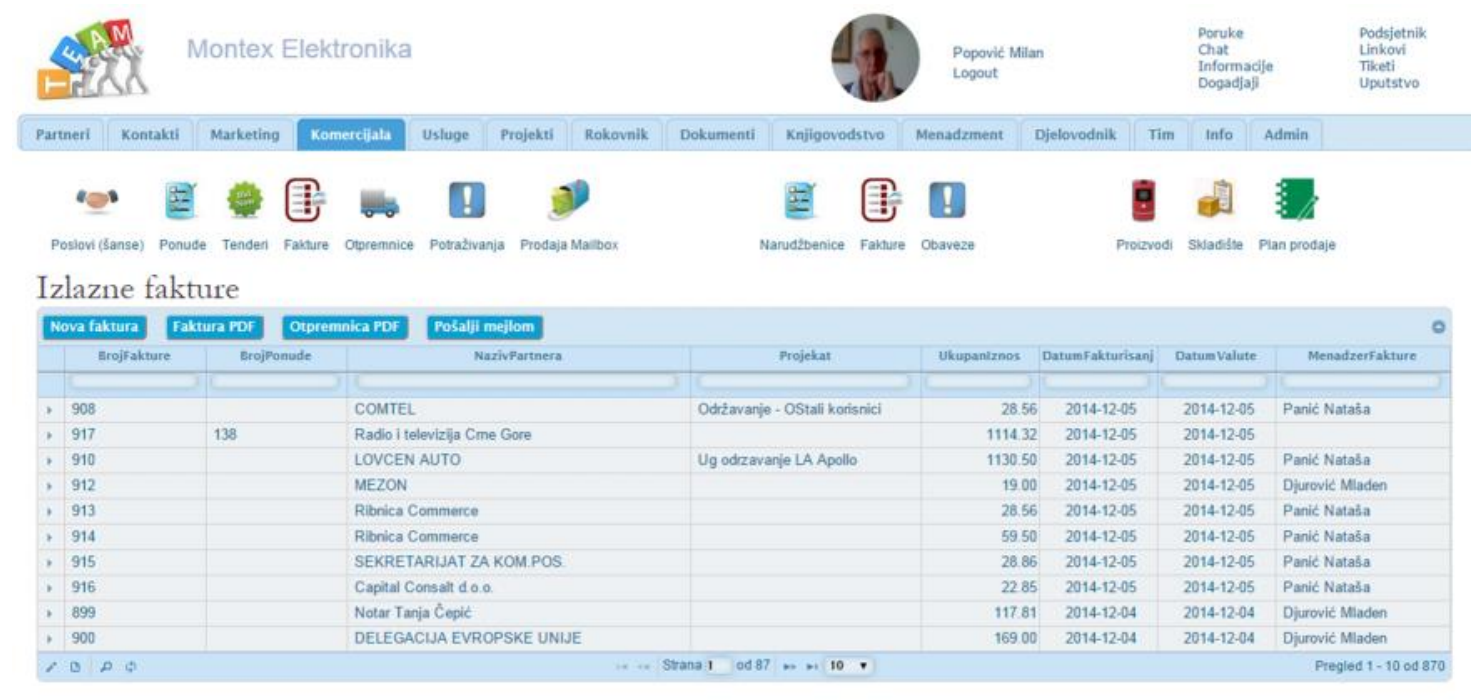

Figure 5 - TimPlaner Invoices 


\section{Montex-Elektronika use of TimPlaner}

By using TimPlaner, ME divides all their business operations in projects, allowing them to implement micromanagement in following areas:

- Software development contracts

- System integration contracts

- System administration and maintenance contracts

- Public tenders contracts

- Sale of ICT equipment contracts

Each contract is treated as separate project with full project life cycle, from pre-project activities, to project (contract) closing and after-sale follow-up and customer support. Projects may be grouped in various ways to make portfolios: by program and project managers, by project's categories, by time periods. By using such a strategy, ME was able to have detailed insight, in real time, of status of every active project.

Main benefits ME experienced using such an approach may be summarized as follows:

- Accurate measuring of the availability of resources allocated to projects.

- Easy separation of main activities from basic tasks.

- Planning projects using the project templates that comply with internal processes and corporate standards.

- Simplifying and accelerating the allocation of resources.

- Following progress of the project in detail through a real-time view of Gantt chart, utilization of budget (financial view) and usage of resources.

- Strengthening collaboration and coordination of project and business teams by centralizing and sharing documents and information.

- Increasing efficiency and responsiveness of all project participants through better communication.

\section{CONCLUSION}

Application of information technologies and related software solutions for efficient management of individual business operations and projects is a necessity that no one questioned. In addition to large companies, the application of information technology is increasingly spreading to SMEs and they are working of development of appropriate software solutions that would help them to quickly and efficiently implement their business operations. If we accept the fact that each business operation can be treated as a project, we come to the real possibilities to apply the principles and methods of project management in this field. As an information support for the efficient implementation of projects companies today are using standard software tools, such as MS Project and Primavera. Since these tools are too complex for SMEs, it is possible to develop special software solutions that are more appropriate for SMEs. Here is shown a software solution that was developed specifically for the needs of SMEs. This software tool is checked on the example of company MONTEX Electronika and it showed very good results in the management of business projects in the company.

\section{REFERENCES}

[1] Parnaby J, Wearne, S., Kochhar, K.A. Managing by Projects for Business Success, Professional Engineering Publishing, Suffolk, UK, 2003.

[2] Šobajić V, Berić I, Kilibarda G. Jovanović P. Upravljanje softverskim projektima, Tehnika 1/2016, p. 145-153, 2016.

[3] Abrahamsson P, Salo O., Ronkainen J., Warsta J. Agile software development methods: Review and analysis, Oulu Finland, VTT Publications, 2002.

[4] Jovanović P, Živković, D, Jovanović F, Menadžment i projektni menadžment, Visoka škola za projektni menadžment, Beograd, 2008.

[5] Popović M, Radulović A, A Software Solution: TimPlaner, Montex-Elektronika, Podgorica, CG, 2012.

[6] A Guide to Project Management Body of Knowledge, Fifth Edition, Project Management Institute, Newton Square, PA, 2012.

\section{REZIME}

\section{RAZVOJ MULTIFUNKCIONALNOG SOFTVERA ZA UPRAVLJANJE POSLOVNIM OPERACIJAMA U MALIM I SREDNJIM PREDUZEĆIMA}

U ovom radu prikazano je web orijentisano softversko rešenje usmereno na podršku efikasnom upravljanju operacijama i projektima u SMEs. Razvoj ovog softvera je tretiran kao poseban projekat, te je korišćena agilna metodologija razvoja softvera i određeni principi i rešenja projektnog menadžmenta, da bi se softverski proizvod isporučio u željenom vremenu i u skladu sa zahtevima klijenta.

Ključne reči: upravljanje pomoću projekata, softveri za upravljanje poslovanjem, mala i srednja preduzeća, portfolio projekata 